\title{
ANALISIS PESAN ANTI RASISME DALAM FILM DEAR WHITE PEOPLE
}

\author{
Reni Juliani \\ Program Studi Ilmu Komunikasi, Fakultas Ilmu Sosial dan Ilmu Politik \\ Universitas Teuku Umar \\ Email: renijuliani@utu.ac.id
}

\begin{abstract}
This study aims to find out what messages are contained in the film Dear White People. Peirce semiotics theory is the underlying theory of this research. This theory deals with indentifying, documenting, and classifying the main types of signs and how they are used in representative activities. Messages ini movies usually depict events or phenomena that are all around us, such as warfare, romance, munder, mafia crimes, rasism, anti rasism and more.a good movie is a movie that has the contents of a message that can be used as inspiration by the movie lovers. A movie can be said to be quality if the theme and content of the message contains a positive and strong meaning. From the result of this study found that the film Dear White People directed by Justin Simien has a message that oppression, discrimination or exclusion of a group, people or groups both minority and majority is a form of racism.the struggle against racism by suppressing the majority with the stereotype that the majority always oppress the minority is a new from of racism.
\end{abstract}

Keywords: Message, Anti Rasisme,Film.

\section{PENDAhuluan}

Arus perkembangan teknologi saat ini semakin berkembang. Perkembangan ini sangatlah mendukung peningkatan komunikasi ke arah yang lebih baik. Saat ini banyak kita temukan berbagai macam alat-alat komunikasi yang diproduksi guna memperlancar proses komunikasi manusia. Dengan adanya alat-alat komunikasi, komunikasi juga dapat dilakukan dengan efektif dan efisien hal ini dikarenakan teknologi yang terus berkembang dan terus mempengaruhi kemajuan teknologi media dalam berkomunikasi.

Teknologi komunikasi bukan hanya sebatas alat-alat yang diproduksi untuk berkomunikasi. Kreatifitas manusia juga semakin berkembang dengan adanya teknologi. Seperti yang kita lihat saat ini. Dengan adanya teknologi manusia dapat mengungkapkan ide mereka tanpa terhalang oleh media. Mereka bahkan bebas memilih media mana yang akan mereka gunakan untuk mengembangkan kreatifitas mereka. Kreatifitas juga tidak terbatas oleh pendidikan dan usia. Hal ini dikarenakan kehadiran teknologi komunikasi yang memudahkan mereka sehingga karya-karya besar bisa tercipta. Salah satunya adalah film.

Perkembangan film saat ini semakin pesat. Kemunculan film sebagai media baru menjadi sebuah perbincangan yang cukup menarik perhatian masyarakat dunia. Besarnya industri perfilman saat ini tidak terlepas dari pesatnya kemajuan teknologi yang ada. Bila pada zaman dahulu kita hanya bisa melihat rekaman gambar bergerak kemudian dimodifikasi menjadi film bisu. Seiring berkembangnya teknik pengambilan gambar, berkembangpula alat-alat produksi film yang menghasilkan film dengan tampilan yang lebih baik dan menarik. Saat ini kita bisa melihat film dengan gambar kualitas HD (high definition) dan suara yang jernih.

Perkembangan film tidak berhenti disitu saja. Pesan yang disampaikan di dalam film juga semakin beragam. Tidak hanya sebatas hiburan semata, dari film kita bisa belajar realita yang terjadi di dunia ini. Banyak film diproduksi berdasarkan kisah nyata yang bertujuan sebagai 
pengingat, pembelajaran, dan perbandingan realitas saat ini dengan zaman terdahulu. Dengan keberagaman genre film yang tersedia, menonton film menjadi kegiatan yang digemari oleh manusia saat ini.Kegiatan menonton film seolah memiliki kenikmatan tersendiri dibandingkan ketika menikmati media yang lain. Penonton diajak merasakan berbagai emosi dan sensasi saat menonton fil. Mulai dari rasa bahagia, marah, sedih, takut bahkan tersinggung.

saat menonton sebuah film, penonton seperti benar-benar mengalami dan merasakan kejadian yang ada dalam film.

Film memiliki kekuatan dalam membentuk sebuah realita yang dapat ditangkap oleh mata manusia. Hal ini yang sering digunakan oleh film maker untuk mengungkapkan realita sebenarnya yang ada di dunia ini. Tidak sedikit mereka membuat propaganda demi kepentingan mereka sendiri sehingga mereka memproduksi film yang mengandung unsur-unsur kebencian terhadap suatu budaya, mengucilkan suatu agama atau menindas suatu ras.

Film dan propaganda mungkin bisa dimaknai secara sosiologis, karena jangkauan film yang bisa menjangkau banyak manusia dan bisa merambah ke segala geografis. Lebih lanjut, film juga dapat diartikan secara psikologi dimana film dapat berisikan beragam pesan yang dapat mempengaruhi penonton. Pengaruh tersebut bahkan akan berbeda tergantung bagaimana penonton menanggapi film tersebut. Bagi Pudovkin sendiri, film bisa dimaknai sebagai 'guru terbaik', karena film dianggap dapat memberikan informasi yang dapat menambah pengetahuan kita dan dapat memperluas wawasan kita, bukan hanya itu, film juga memberikan pengaruh pada seluruh tubuh penontonnya (Yumni, 2013).

Untuk mengatasi hal tersebut, film maker yang tidak sependapat dengan isu propaganda tersebut membuat film yang menentang aksi-aksi propaganda dan rasisme. Mereka bahkan serta merta membuat film dengan mendukung anti-rasisme. Seperti halnya film Dear White People. Film ini menyuarakan anti-rasisme sehingga mengajak penonton melihat bagaimana rasisme terjadi pada bangsa kulit hitam. Oleh sebab itu penelitian ini ingin mengetahi apa pesan sebenarnya dalam film Dear White People.

\section{KAJIAN PUSTAKA}

\section{Rasisme}

Apabila kita mendengar kata rasisme, terlintas dibenak kita mengenai penindasan dan diskriminasi terhadap kaum minoritas. Dewasa ini kita banyak membaca, melihat dan mendengar mengenai isu rasisme yang telah terjadi di dunia. Penindasan terhadap suatu ras disebut rasisme. Sebagai contoh Rezim Hitler yang memberantas ras Yahudi, Gipsi dan ras yang bukan ras Arya adalah bentuk rasisme. Contoh lainya terjadi di Rwanda saat pertikaian antara ras Hutu dan Tutsi. Juga pada ras kulit putih dan ras kulit hitam. Segala bentuk diskriminasi, baik melalui kekerasan fisik maupu perkataan bisa digolongkan kepada tindakan rasisme.

Alo Liliweri (Minfadillah, 2016:23) menjelaskan mengenai asal kata dari rasisme. Menurutnya kata tersebut berasal dari kata ras yang diambil dari bahasa Prancis dan Italia yaitu "razza". Kata "razza" ini dapat diartikan yang pertama yaitu sebagai perbedaan yang beragam dari penduduk atau perbedaan keberadaan manusia yang didasarkan atas:

1) Tampilan fisik yang dapat dilihat langsung dari penglihatan seseorang. Misalkan warna rambut seseorang bisa berbeda dengan orang lain yang berasal dari kelompok lain. contohnya orang yang berambut pirang dan lurus identik dengan ras Amerika sedangkan rambu hitam dan keriting biasanya identik dengan ras Negro. Contoh lain dari perbedaan fisik seseorang antara lain perbedaan warna mata, kulit, bentuk tubuh. Perbedaan fisik ini dapat dibedakan ke dalam 3 golongan atau ketiganya sering disebut dengan ras yaitu: Kaukasoid, Negroid dan Mongoloid.;

2) Tipe atau golongan keturunan. Di Indonesia keterunan seseorang bahkan dapat dibedakan. Ada yang berasal dari keluarga kerajaan yang dapat dibedakan dari 
namanya, seperti nama Andi dari suku Bugis-Makassar, atau Teuku atau Cut dari Aceh dan sebagainya;

3) Pola-pola keturunan; seperti dari suku tertentu. Misalkan suku batak. Suku batak ini malah dibagi ke beberapa golongan lagi, antara lainnya adalah suku batak karo, suku batak mandailing, suku batak toba, suku batak simalungan, dan suku batak pakpak.

4) Semua kelakuan bawaan yang tergolong unik sehingga mereka dibedakan dengan penduduk asli. Hal ini mudah didapatkan dari golongan masyarakat yang berpindah ke suatu daerah lainnya. Misalnya masyarakat desa yang pindah ke kota, kelakuan mereka akan berbeda dengan kelakuan masyarakat yang sudah tinggal di kota.

Selanjutnya pengertian ras Kedua menurut Alo Liliweri (Minfadillah, 2016:24), bahwa ras tersebut menyatakan tentang identitas berdasarkan:

1) Sekelompok orang yang memiliki perangai tertentu;

2) Kualitas perangai tertentu dari suatu kelompok penduduk;

3) Menyatakan eksistensi atau keberadaan suatu kelompok berdasarkan geografi tertentu;

4) Menyatakan tanda-tanda aktivitas suatu kelompok berdasarkan kebiasaan, gagasan dan cara berpikir;

5) Sekelompok orang yang memiliki kesamaan keturunan, keluarga, klan atau hubungan kekeluargaan dan

6) Arti biologis yang menunjukkan adanya subspesies atau varietas, kelahiran, atau kejadian dari sutau spesies tertentu.

Anti rasisme berasal dari dua kata yakni anti dan rasisme. Kata anti menurut Kamus Besar Bahasa Indonesia Online berarti melawan, menentang, memusuhi. Sedangkan rasisme menurut Kombium adalah sebuah pandangan yang memandang rendah suatu kelompok yang mempunyai ciri tertentu yang dibawanya sejak lahir sehingga mereka membuat perbedaan dan melakukan diskriminasi kepada kelompok tersebut. Jadi anti rasisme berarti penentangan terhadap perilaku mendiskriminasikan suatu kelompok dikarenakan ciri tertentu yang membedakan mereka. Anti rasisme adalah pandangan menentang rasisme (Shinta, 2010:28).

\section{Film}

Seni sudah digunakan sejak zaman Yunani klasik yaitu sebagai alat edukasi maupun sebagai alat politik. Seni tersebut berupa program musik. Sebagai contoh seni yang dilakukan pada masa itu sebagai alat edukasi adalah program musik tersebut diceritakan melalui mitos untuk pendidikan anak, sedangkan sebagai alat politik, program musik digunakan untuk memupuk semangat dan keberanian para prajurit. Sejak zaman Yunani klasik pula seni sudah mulai membawa ideologi tertentu, seperti pandangan yang menekankan 'harmoni', keutamaan keberanian, dan pelarangan terhadap seni yang mengumbar 'keluh-kesah'. Menurut Vladimir Lenin, film merupakanbentuk seni yang paling penting. Hal ini dikarenakan Lenin menyadari bahwa kemampuan film sangat luar biasa. Film dapat menjangkau khalayak luas masyarakat. Andre Bazin pun menyatakan film adalah seni yang fungsional karena mengandaikan adanya penonton. Daya sosiologis pada film ini, telah disadari betul oleh para pelaku politik untuk mengembangkan gagasan ideologi tertentu dalam mempengaruhi massa penonton. Film tidak saja memiliki kemampuan menjangkau khalayak luas, namum film bisa menjadi alat propaganda yang dimanfaatkan oleh pihak yang berkepentingan. Selain itu juga menyajikan bagaimana kenyataan dari suatu peristiwa melalui visual adalah sesuatu yang sentrifugal terhadap kehidupan nyata (Yumni, 2013).

Kehadiran film semakin masa semakin berubah. Film yang tadinya hanya sebagai alat presentasi dan distribusi dari hiburan yang lebih tua berubah menjadi film yang menghadirkan cerita tertentu dengan tema tertentu, bahkan ada yang dipentaskan di atas panggung, diisi dengan musik-musik latar, drama, humor, dan berbagai trik serta teknik yang terus berkembang untuk memenuhi tuntutan penonton. Film kini mampu menjadi media massa yang 
sesungguhnya dalam artian bahwa film dapat menjangkau seluruh masyarakat dengan jumlah yang tidak terbatas. Bahkan dengan waktu yang singkat. Salah satu elemen penting dari sejarah perfilman adalah penggunaan film sebagai media propaganda berdasarkan jangkauannya, sifatnya yang riil dampak emosional dan juga popularitas (McQuail, 2011: 35-36).

Film membuka peluang baru bagi pekerja seni. Selain menguntungkan bagi mereka. Kehadira film juga menguntungkan bagi pengusaha-pengusaha lainnya. Seperti yang kita lihat bagaimana menjamurnya bioskop-bioskop di berbagai daerah. Bahkan dalam satu Mall terdapat lebih dari satu bioskop tersedia disana. Hal ini karena meningkatnya jumlah pencinta film dan meningkatnya jumlah film luar yang masuk ke Indonesia. Masyarakat bahkan merasakan sensasi berbeda ketika menonton film di bioskop dari pada menonton film di rumah melalui televisi. Mereka bahkan rela menghabiskan sejumlah dana hanya untuk kepuasan menonton film di bioskop. Selain itu, fasilitas lengkap tersedia di bioskop, mulai dari kamar kecil, snack dan minuman, sofa untuk menunggu giliran masuk ke gedung teater. Fasilitas tersebut guna menambah kenyaman dan meningkatkan loyalitas penonton bioskop.

Industri film merupakan industri yang kreatif. Hal ini dikarenakan kehadiran industri ini dapat melahirkan berbagai ide-ide kreatif baru yang dapat berguna dalam menyampaikan cerita baru yang disajika dalam sebuah film. Kemudian kehadiran cerita baru tersebut diharapkan agar harapan manusia akan pencarian informasi dapat terpenuhi. Selain itu kehadiran film dengan ide-ide baru dapat menghibur manusia. Trianton mengelompokkan film kedalam dua kategori, yaitu film cerita dan film noncerita. Film cerita misalnya; drama, komedi, romantis, horror, action, fiksi, dan lain-lain. Sedangkan film noncerita, misalnya; film documenter dan film factual (Trianton, 2013: 29).

Film terdapat berbagai macam genre. Dalam satu film, biasanya terdapat lebih dari satu genre, akan tetapi diantara banyaknya genre tersebut, pasti terdapat salah satu genre yang lebih dominan lagi.Genre ini terdapat beberapa macam diantaranya (Tanjung, 2017):

1) Action, merupakan sebuah genre yang digunakan bagi jenis film yang mengandung banyak sekali gerakan dinamis para aktor maupun aktris dalam sebagian besar adegan film, seperti aksi bela diri, baku tembak, kejar mengejar, ledakan dan lain-lain.

2) Adventure, merupakan jenis genre yang digunakan pada film yang lebih condong pada sebuah alur petualangan yang banyak sekali mengandung teka-teki pada filmnya.

3) Animation, merupakan jenis genre yang digunakan film animasi dengan berbagai macam alur. Genre film ini biasanya sering dinikmati oleh kalangan anak-anak, namun sekarang industri perfilman mulai mengembangkannya sehingga dapat dinikmati banyak kalangan.

4) Biography, merupakan jenis genre yang digunakan film bertema sejarah, perjalanan hidup atau karir seseorang (biasanya tokoh masyarakat) maupun suatu kelompok.

5) Comedy, merupakan jenis genre yang digunakan film dengan banyak sekali adegan komedi dan lelucon pada alur ceritanya. Biasanya film comedy akan menyisipkan beberapa kata-kata kotor maupun yang bersifat rasis agar lebih menarik dan lucu.

6) Crime, merupakan jenis genre yang digunakan film berskenario kejahatan kriminal sebagai inti dari alur ceritanya.

7) Documentary, merupakan jenis genre yang digunakan film berisi tentang kejadian maupun peristiwa yang terjadi berdasarkan kisah nyata.

8) Drama, merupakan jenis genre yang digunakan pada film bertemakan percintaan, kehidupan, sosial dan lain-lain dengan sebuah alur tertentu.

9) Family, merupakan jenis genre yang digunakan pada film berceritakan hal yang dapat dinikmati bersama-sama dengan keluarga, yang berarti tidak ada unsur saranya.

10) Fantasy, merupakan jenis genre yang digunakan pada film bersifat imajinatif, yang mana seluruh model dari karakter maupun tokoh dari filmnya berdasarkan imajinasi yang tidak ada di dunia nyata. Biasanya, diperlukan efek visual yang bagus agar 
hasilnya memuaskan.

11) Film-Noir, merupakan sebuah istilah yang digunakan untuk menggambarkan gaya perfilman Hollywood yang menampilkan nuansa kriminal.

12) Game-Show, merupakan jenis genre yang digunakan pada film yang bertemakan sebuah pertunjukan, permainan maupun perlombaan yang mana hal tersebutlah yang dihadikan sebagai inti dari ceritanya.

13) History, merupakan jenis genre yang digunakan pada film berceritakan pada masa lalu sesuai dengan kejadian dan peristiwa yang telah menjadi sejarah. Genre ini hampir mirip dengan Documentary.

14) Horror, merupakan sebuah jenis genre yang digunakan pada film berisi kejadiankejadian mistis dan berhubungan dengan kejadian yang menyeramkan sebagai inti dari cerita filmnya.

15) Musical, merupakan jenis genre yang digunakan pada film bertemakan drama musikal, dimana yang lebih ditonjolkan pada alurnya adalah aksi musiknya.

16) Mystery, merupakan jenis genre yang digunakan pada film berunsur penuh akan tekateki pada alurnya, biasanya kalian akan mendapat ending yang tidak terduga dan membuat kalian takjub akan film tersebut (plot twist).

17) Romance, merupakan jenis genre yang digunakan pada film berisi tentang kisah-kisah percintaan anak muda maupun dewasa.

18) News, merupakan jenis genre yang digunakan pada film dengan alur yang memberikan banyak sekali informasi tentang suatu hal dan bersifat informatif.

19) Sci-Fi, merupakan jenis genre yang digunakan pada film pengetahuan yang bersifat perkembangan teknologi modern dan lebih condong pada penemuan-penemuan teknologi paling canggih yang belum ada di kehidupan sebenarnya.

20) Sport, merupakan jenis genre yang digunakan pada film berlatar belakang mengenai olah raga sebagai alur ceritanya.

21) Thriller, merupakan jenis genre yang digunakan pada film penuh akan aksi mendebarkan dan biasanya alur dari ceritanya menantang, penuh aksi dan mendapat berbagai bantuan. Ketahuilah, pemeran utama di sini bisa sebagai orang baik, namun bisa juga sebagai penjahat.

22) War, merupakan jenis genre yang digunakan pada film berceritakan peperangan baik modern maupun zama dahulu.

23) Western, merupakan jenis genre yang digunakan pada film berisikan suku di amerika dan kehidupan maupun kebudayaan dari suku indian yang biasanya terdapat juga seorang tokoh koboi berkuda, seorang sheriff dan aksi tembak menembak.

\section{Semiotika}

Kata "semiotiks" sebenarnya merupakan kata yang berasal dari bahasa Yunani, yaitu semeion yang berarti "tanda" atau seme, yang berarti "penafsiran tanda". Semiotika sendiri sebenarnya bersumber dari studi klasik dan skolastik atas seni logika, retorika, dan poetika. Dapat disimpulkan bahwa dasar dari semiotika adalah kode. Studi mengenai kode-kode ini berupa sistem apapun yang memungkinkan kita memandang entitas-entitas tertentu sebagai tanda-tanda atau sesuatu yang bermakna (Nisa, $2014: 11$ ).

Semiotika diartikan pengkajian tanda bila dinilai secara etimologis. Tanda tersebut merupakan dasar dari komunikasi.Dimana dengan adanya perantara tanda-tanda, manusia dapat melakukan komunikasi dengan sesamanya. Selain itu yang harus diperhatikan dalam semiotika adalah tugas pokok yang bertujuan untuk mengidentifikasi, mendokumentasikan, dan mengklasifikasikan tanda-tanda yang beragam jenisnya dan bagaiman tanda tersebut digunakandalam aktivitas yang bersifat representatif. (Karima dan Christin, 2015:2240).

Sejalan dengan apa yang disebutkan oleh Peirce bahwa semiotika merupakan pemikiran 
terhadap tanda yang berhubungan dengan orang lain dalam kita berkomunikasi. Tanda tersebut mempunyai makna tertentu sesuai dengan yang ditampilkan oleh alam semesta. Tanda-tanda berkaitan dengan objek-objek yang menyerupainya dan memiliki hubungan sebab-akibat. Tugas penganut semiotika Peirce untuk menemukan koherensi dan menyaring hal-hal yang penting. Peirce mengehendaki agar teorinya yang bersifat umum ini dapat diterapkan pada segala macam tanda, dan untuk mencapai tujuan tersebut, ia memerlukan konsep-konsep baru. Untuk melengkapi konsep itu ia menciptakan kata-kata baru yang diciptakannya sendiri (Kaelan, 2009: 166).

Istilah kata semiotika disamping kata semiologi sampai kini masih dipakai. Namun banyak pakar menggunakan istilah-istilah lain dalam dunia linguistik. Istilah terbeut antara lainsemasiologi, sememik dan semik untuk merujuk pada bidang studi yang mempelajari makna atau arti dari suatu tanda lambang (Subur, 2009:11).

\section{HASIL DAN PEMBAHASAN}

\section{Penindasan Bangsa Kulit Hitam}

Sejarah kolonisasi bangsa-bangsa Eropa terhadap bangsa-bangsa non-Eropa (Amerika, Asia, Australia, dan Afrika), tidak pertama-tama didasarkan oleh motif rasial. Kala itu, pengetahuan orang Eropa terhadap penduduk non-Eropa masih sangat minim. Motif pertama dan utama penjajahan dan kolonilasi adalah untuk mencari sumber-sumber kekayaan ekonomi dan kemudian mengakumulasinya. Untuk menjaga agar proses akumulasi itu berjalan tanpa gangguan maka dibangunlah kekuatan politik dan militer di daerah-daerah jajahan. Melalui supremasi politik dan militer ini rakyat jajahan ditaklukkan dan diperbudak dengan cara-cara kekerasan. Di sisi koin yang sama, penguasa kolonial juga memproduksi bahan-bahan bacaan dan produk-produk kultural lainnya untuk menunjukkan bahwa mereka secara kodrati memang lebih superior dari rakyat jajahannya. Sementara kepada rakyat jajahannya ditanamkan sikap inferioritas atau minder: kalian terbelakang karena bodoh, penyakitan, pemalas, cepat puas dengan kondisi yang sudah ada, tergantung pada apa maunya pemimpin, suka bertengkar dengan sesamanya, dsb, dsb. Bahkan mereka berteori bahwa secara genetika orang Eropa yang berkulit putih itu memang lebih unggul dari ras lainnya di muka bumi ini. Melalui dua modus operandi ini, kolonisasi dilakukan dengan secara sistematis (Pontoh, 2016).

Amerika mempunya sejarah panjang mengenai rasisme sejak abad ke 16 yaitu bentuk perbudakan warga kulit hitam. Pada awalnya, orang-orang kulit hitam dipekerjakan oleh Amereka untuk membantu mereka mengelola perkebunannya terlebih membantu mereka dalam mengerjakan hal-hal yang cenderung berat. Namun seiring berjalannya waktu, keberadaan orang kulit hitam sebagai pekerja semakin berubah. Orang-orang yang mereka pekerjakan mulai diperlakukan semena-mena sehingga mengakibatkan banyak korban perbudakan yang berjatuhan dari masa ke masa dikarenakan tindakan tidak manusiawi yang dilakukan oleh orang Amerika. Pemerintah Amerika mengeluarkan peraturan untuk menghapus segala macam jenis perbudakan yang ada di negara tersebut pada tahun 1807. Hal ini dikarenakan jumlah korban yang teraniaya semakin bertambah jumlahnya dan ulah orang Amerika terhadap pekerja mereka semakin tidak terbatas. Pada tahun 1808 diharapkan peraturan ini dapat mulai dijalani dan korban-korban semakin berkurang, namun kenyataannya sangatlah berbeda. Berdasarkan data dari Historical Statistic of the U.S pada tahun 1970 terlihat sangat jelas peningkatan korban perbudakan yang justru semakin signifikan sejak tahun 1800 menuju tahun 1900 terutama pada negara Amerika bagian selatan dikarenakan kebutuhan mereka akan tenaga kasar yang sangat besar untuk pekerjaan di ladang mereka (Widjaja, 2016:1).

Penindasan yang dilakukan oleh Amerika bukan hanya penindasan hak. Namun mereka telah menyiksa pekerja kulit hitam, terjadinya pelecehan seksual terhadap wanita-wanita kulit hitam. Wanita-wanita tersebut dijadikan pembantu untuk mengurusi anak-anak mereka juga melakukan pekerjaan rumah. Pendidikan tidak diberikan kepada mereka. Amerika seakan 
menganggap kaum kulit hitam dihadirkan di dunia untuk membantu pekerjaan mereka di ladang maupun dirumah.

Selama ratusan tahun tidak ada bagian kehidupan di Afrika Selatan yang tidak diatur oleh pemisahan ras. Namun sejak Partai Nasional de Boer 1948, setelah Perang Dunia ke-2, memenangkan pemilihan umum dan membentuk pemerintahan minoritas kulit putih, sistem apartheid kemudian ditetapkan dalam undang-undang. Pada tahun 1950, Undang-undang Pendaftaran Populasi semua warga Afrika Selatan dibagi dalam tiga kategori ras, yaitu Bantu atau Afrika kulit hitam, kulit putih dan kulit berwarna lainnya. Kemudian ada kategori baru, yaitu Asia yang sebagian besarnya adalah warga etnis India dan Pakistan.Afrika Selatan kemudian dibagi. 80 persen wilayah negara itu dimiliki warga kulit putih. Sementara warga kulit hitam ditempatkan di wilayah termiskin yang disebut sebagai homelands atau tanah air. Mereka memiliki semacam pemerintahan administrasi mandiri. Mereka secara ekonomi, sosial dan politik dikucilkan. Pada tahun 1970 diberlakukan Undang-Undang Kewarganegaraan Tanah Air Bantu. Semua warga kulit hitam harus bertempat tinggal di "homeland", atau tanah air, suatu wilayah yang dihuni mayoritas kulit hitam Afrika. Warga homelands harus membawa paspornya untuk dapat meninggalkan wilayahnya (Jeppesen, 2010).

Pemisahan warga kulit putih dan hitam juga diberlakukan di fasilitas umum. Gedunggedung umum, transportasi umum, taman-taman, rumah makan, serta tentu sekolah-sekolah, perguruan tinggi, rumah sakit dan gereja. Daerah-daerah permukiman di setiap kota dan desa juga dibagi dua, sistem pendidikan sekolah terpisah dengan kualitas guru yang berbeda, dan hanya warga kulit putih yang memiliki hak pilih (Jeppesen, 2010).

UNESCO mencoba untuk menyelamatkan bangsa kulit hitam yang ditindas oleh bangsa kulit putih. Oleh sebab itu pada tahun 1950, UNESCO menyatakan bahwa semua manusia di bumi adalah sama sebagai homo sapiens yang terdiri dari sejumlah populasi. Sama dalam artian setiap manusia tidaklah berbeda walaupun berbeda bangsa. Populasi yang besar disebut ras, dan belum ada bukti ilmiah yang menunjukkan bahwa perbedaan biologis juga identik dengan perbedaan kemampuan intelektua;. Di samping itu ras yang berbeda dapat melakukan kawin campur antar ras tanpa menimbulkan cacat biologis. Berdasarkan hal tersebut, mestinya semua manusia di bumi bisa hidup dengan damai dan tidak berkonflik satu dengan yang lain, karena semua manusia adalah sama-sama homo sapiens (Al Hafizh, 2016:178).

Konsepsi mengenai perbedaan warna kulit, mata, rambut atau postur tubuh yang merupakan ciri tubuh manusia itu telah melahirkan serangkaian kesedihan dan kesengsaraan bagi bangsa yang merasakn diskriminasi ras. Bahkan hingga saat ini, diakui atau tidak, masalah rasisme tetap menjadi sesuatu polemik bagi negara multi etnik, termasuk Amerika. Terlepas Barak Obama, yang merupakan warga kulit hitam dan telah berhasil mengukuhkan diri sebagai orang nomor satu di negara adi daya tersebut, isu-isu rasial bahkan masih kental menyelimutinya (Sawitri, 2009:2).

\section{Pesan dalam Film Dear White People}

Pesan merupakan salah satu unsur penting dalam proses komunikasi. Komunikasi dapat disampaikan dalam berbagai media, termasuk film. Dalam film, ada pesan-pesan yang terkandung di dalamnya dan disampaikan kepada penonton yang menonton film tersebut. Dapat diartikan pesan dalam sebuah film biasanya refleksi dari sebuahperistiwa atau fenomena yang berada disekitar kita, yang dicoba untuk ditampilkan kembali kepada penonton. Peristiwa tersebut bisa berupa peristiwa sejara seperti peperangan, atau kisah-kisah romantis, kriminal, kejahatan dan banyak lagi yang lainnya. Film yang bagus adalah film yang memiliki isi pesan yang mampu dijadikan sebagai inspirasi oleh para penikmat film. Hal ini menyangkut kualitas sebuah film dimana jika tema dan isi pesannya mengandung makna yang positif dan bersifat kuat serta dapat berhasil mempengaruhi penonton sesuai yang diharapkan oleh pembuat film. Sehingga film tersebut dapat menggugah nurani serta emosi dari penonton yang menjadikan 
film tersebut akan terus dikenang dan selalu melekat di kepala masyarakat luas, bukan sekedar terhibur dari apa yang mereka lihat (Kurniawan, 2011:4).

Saat ini banyak film yang mengangkat isu-isu rasisme. Film-film dengan tema seperti tersebut selain menjadi pengetahuan bagi penonton yang belum mengetahui mengenai rasisme, juga menjadi pembangkit luka lama bagi mereka korban rasisme. Oleh sebab itu beberapa ada beberapa film dibuat untuk menentang rasisme tersebut. Salah satunya adalah film Dear White People. Film ini secara garis besar memang menampilkan bagaimana rasisme terjadi di dunia kampus yang di dominasi oleh ras kulit putih sedangkan ras kulit hitam menadi minoritas dan sering tertindas di kampus tersebut.

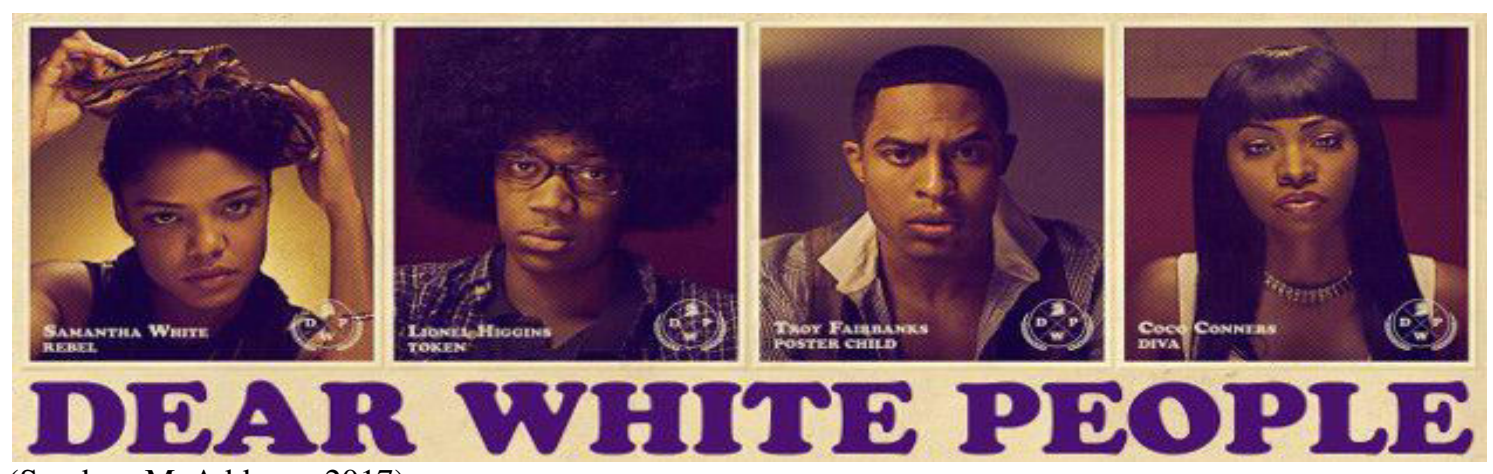

(Sumber: McAddams, 2017)

Diskriminasi ras telah muncul sejak puluhan dekade lalu dan terkadang masih menjadi isu hingga sekarang, terutama di Amerika Serikat. Isu diskrimasi ras sendiri seringnya disebabkan oleh perbedaan warna kulit dan fisik. Banyak perlakuan tidak adil yang sering diterima oleh orang kulit hitam dari orang kulit putih. Ketidakadilan ini kemudian menjadi isu sosial yang cukup menarik perhatian para sineas film. Banyak film bertema rasisme yang dibuat untuk menyuarakan ketidakadilan yang dialami orang kulit hitam ataupun ras lain. Salah satu film bertema rasisme yang cukup menyita perhatian para pecinta film adalah Dear White People. Film arahan Justin Simien ini bercerita tentang 4 mahasiswa Afro-Amerika yang menempuh pendidikan di Universitas Winchester. Mereka memiliki masalah dan cerita masing-masing yang menggambarkan kehidupan mereka sebagai orang kulit hitam (Susma, 2017). Film ini dibintangi oleh Tyler James Williams, Tessa Thompson, Teyonah Parris, Brandon P Bell, Kyle Gallner, Brittany Curran, Marque Richardson dan Dennis Haysbert (Dory, 2014).

Sementara itu, nama Dear White People sendiri diambil dari acara radio milik Sam White yang merupakan wanita keturunan Afro-Amerika. Acara radio ini tidak seperti acara radio lainnya. Acara radio ini justru dibuat untuk menyuarakan isu diskriminasi ras yang sudah seharusnya dihentikan. Sam White juga secara lantang membeberkan ketidakadilan yang dia alami selama menempuh pendidikan di Universitas Winchester. Beberapa kritikus film bahkan menyebut film yang dirilis pada tahun 2014 ini sebagai film satir atau sindiran terhadap isu sosial yang masih menjadi masalah utama di Amerika Serikat hingga sekarang.Film ini sempat menyinggung masalah rasisme yang sedikit berbeda dengan film bertema rasisme yang lain. (Susma, 2017).

Pada menit kedua film Dear White People, kita sebagai penonton telah bias menilai arah dari film tersebut. Anti rasisme sagat jelas terlihat saat seorang reporter di televisi menyampaikan informasi bahwa pihak Universitas Winchester sangat menyayangkan kerusuhan yang terjadi antara ras kulit putih dan ras kulit hitam. Oleh sebab itu Universitas Winchester menghimbau kepada seluruh undangan pesta Halloween untuk menghormati Negro.

Pada pertengahan film tepatnya di jam pertama menit kedua saat Dr. Walter Fairbanks, 
dekan di Universitas Winchester memanggil Sam yang melitas terburu-buru di depannya. Dalam adegan tersebut dapat kita simpulkan bahwa Fairbanks menjelaskan kepada Sam bahwa apa yang diperjuangkan oleh Sam selama ini adalah keliru. Sam menganggap pergolakannya adalah untuk menyadarkan masyarakat akan penindasan terhadap ras kulit hitam. Fairbank menjelaskan yang dilakukan Sam sebenarnya bukan melawan rasisme, namun Sam sendiri melakukan rasis. Menurut Sam "Kulit hitam tidak bisa rasis. Rasisme menggambarkan kerugian dari suatu sistem yang berdasarkan ras, tapi kulit hitam tidak bisa rasis karena tidak mengambil keuntungan dari sistem tersebut."

Apakah yang dilakukan Sam dan teman-temannya merupakan perjuangan melawan rasisme? Atau justru sebaliknya mereka yang menerapkan rasisme tersebut? Mereka merasa bahwa semua orang kulit putih memberikan stereotip pada kaum kulit hitam. Bukankah pernyataan itu sendiri berupa stereotip? Mereka mengusir, bahkan melempari orang kulit putih karena berkumpul di asrama kulit hitam. Bukankah itu juga penindasan? Apakah mengintimidasi ras lain untuk membela ras mereka sendiri disebut sebagai perjuangan melawan rasisme atau justru termasuk tindakan rasisme itu sendiri?

Film ini fokus pada kesetaraan ras dimana setiap manusia berhak diperlakukan secara adil, baik itu ras kulit hitam maupun ras kulit putih. Film ini menyadarkan kita bahwa kita terkadang selalu berfikir bahwa rasisme adalah menindasan dan diskriminasi yang dilakukan oleh ras berkulit putih kepada ras berkulit hitam. Namun sesungguhnya makna dari rasisme itu sendiri perlu diperbaiki pemahamannya. Apapun yang mengarah terhadap penindasan, pengucilan dan ketidaksewenang-wenangan terhadap suatu kaum minoritas bisa disebut dengan rasisme. Tentu saja saat itu yang menjadi fokus adalah kesetaraan ras. Berjuang melawan rasisme atau bersikap anti rasis sesungguhnya esensi dari kalimat perjuangannya secara keseluruhan hanya satu: kesetaraan.

Kata kesetaraan berarti sama tinggi dan sama rendah, tidak ada yang membedakan antara mereka. Seperti salah satu peribahasa dalam bahasa Indonesia yaitu "Duduk sama rendah, berdiri sama tinggi". Hal ini menggambarkan kesamarataan atau kesetaraan yang tidak membeda-bedakan seseorang dengan orang lain, kelompok satu dengan kelompok lainnya, atau bangsa itu dengan bangsa ini. Peribahasa ini menunjukkan dan menanamkan nilai moral kepada kita bahwa manusia dianggap sama. Tidak peduli mereka berasal dari ras, agama, budaya atau jenis kelamin yang berbeda.Kesetaraan bukan semata-mata siapa yang mayor dan siapa yang minor. Itu adalah tentang menjadi manusia yang tidak punya perbedaan satu sama lain.

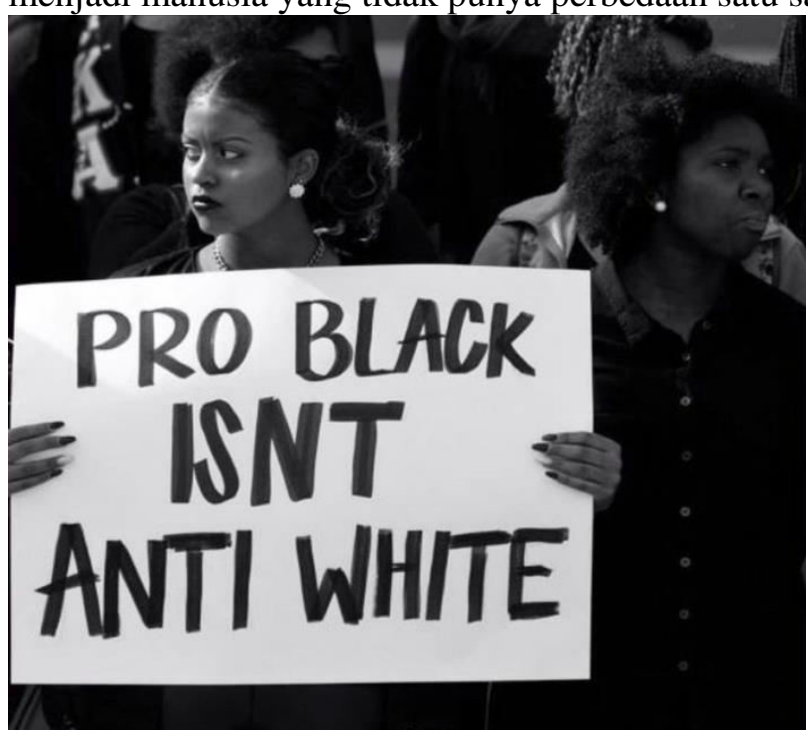

(Sumber:WilMacks, 2016) 
Rasisme dalam bentuk apapun merupakan hal yang sepantasnya dilawan. Berjuang memberantas penindasan bagi kaum minoritas adalah wajib hukumnya, tapi bukan berarti kamu bisa berlaku seenaknya pada mayoritas. Seperti yang digambarkan di film tersebut dimana mereka melawan mayoritas dengan juga menindas mereka. Hal demikian berarti kau melakukan rasisme yang sebenarnya kamu benci. Perlawanan rasialisme yang kebablasan itu dapat menimbulkan rasisme baru yaitu rasisme kepada kaum mayoritas. Dan tanpa kita sadari film tersebut telah mengungkapkan realita yang terjadi saat ini.

Apabila membahas mengenai tanda sesuai dengan teori semiotika Peirce, maka dalam film Dear White People ini kita bisa melihat tanda yang mereka buat yang menjurus pada rasisme. Misalnya rambut yang lurus hanya untuk ras kulit putih sedangkan rambut keriting penanda ras kulit hitam. Sam yang memiliki acara siaran radio dengan jusul Dear White People memiliki buku dengan cover beberapa kepala berwarna putih namun hanya satu kepala berwarna hitam. Hal ini dimaksud bahwa ras kulit putih menjadi mayoritas di atas ras kulit hitam yang menjadi minoritas.

Tanda-tanda lain dalam film ini dilihat pada saat pesta Halloween, ras kulit putih berpesta dengan kostum ras kulit hitam. Ada yang mewarnai kulitnya menjadi hitam, menggunakan pakaian $\mathrm{R} \& \mathrm{~B}$ dan menjadi rapper, menggunakan rambut palsu yang keriting, menggunakan topeng dengan wajah berkulit hitam seperti menggunakan topeng muka Obama, presiden Amerika Serikat saat itu. Selain itu banyak poster ditempel di dinding dengan tulisan Missing Black Culture yang berarti budaya kulit hitam yang hilang.

Film Dear White People garapan Justrin Simien ini terlihat jelas tidak memihak kepada suatu ras atau golongan. Film tersebut memaparkan realita yang ada yang terjadi di Amerika. Walaupun ras kulit hitam pernah menjadi orang nomor satu di Amerika, hal ini tidak menjadikan penindasan ras kulit hitam hilang dari Amerika. Dalam filmnya tersebut dapat kita lihat bahwa realitanya penindasan masih ada walaupun beberapa sudah menerima perbedaan mereka, namun tidak bisa dipungkiri bahwa rasisme masih terjadi.

Di Indonesia, telah ada regulasi yang melindungi hak-hak golongan. Dalam UndangUndang Republik Indonesia Nomor 40Tahun 2008 Tentang Penghapusan Diskriminasi Ras Dan EtnisMenimbang :

a) Bahwa umat manusia berkedudukan sama di hadapan Tuhan Yang Maha Esa dan umat manusia dilahirkan dengan martabat dan hak-hak yang sama tanpa perbedaan apa pun, baik ras maupun etnis;

b) Bahwa segala tindakan diskriminasi ras dan etnis bertentangan dengan nilai-nilai Pancasila, UndangUndang Dasar Negara Republik Indonesia Tahun 1945, dan Deklarasi Universal Hak Asasi Manusia;

c) Bahwa segala warga negara bersamaan kedudukannya di dalam hukum dan berhak atas perlindungan terhadap setiap bentuk diskriminasi ras dan etnis;

d) Bahwa adanya diskriminasi ras dan etnis dalam kehidupan bermasyarakat merupakan hambatan bagi hubungan kekeluargaan, persaudaraan, persahabatan, perdamaian, keserasian, keamanan, dan kehidupan bermata pencaharian di antara warga negara yang pada dasarnya selalu hidup berdampingan;

e) Bahwa berdasarkan pertimbangan sebagaimana dimaksud dalam huruf a, huruf b, huruf c, dan huruf d perlu membentuk Undang-Undang tentang Penghapusan Diskriminasi Ras dan Etnis;

Pada Undang-Undang Republik Indonesia Nomor 40Tahun 2008 Tentang Penghapusan Diskriminasi Ras Dan Etnis dinyatakan dalam Bab VIII Ketentuan Pidana Pasal 15 bahwa setiap orang yang dengan sengaja melakukan pembedaan, pengecualian, pembatasan, atau pemilihan berdasarkan pada ras dan etnis yang mengakibatkan pencabutan atau pengurangan pengakuan, perolehan atau pelaksanaan hak asasi manusia dan kebebasan dasar dalam suatu 
kesetaraan di bidang sipil, politik, ekonomi, sosial, dan budaya sebagaimana dimaksud dalam Pasal 4 huruf a, dipidana dengan pidana penjara paling lama 1 (satu) tahun dan/atau denda paling banyak Rp100.000.000,00 (seratus juta rupiah).

\section{SIMPULAN}

Film Dear White People garapan Justrin Simien mempunyai pesan bahwa penindasan, dikriminasi, atau pengucilan terhadap suatu golongan, kaum maupun kelompok baik minoritas maupun mayoritas merupakan bentuk rasisme. Perjuangan melawan rasisme dengan menindas kelompok mayoritas mempunyai stereotip bahwa kelompok mayoritas selalu menindas kelompok minoritas, hal ini merupakan rasisme bentuk baru.

Tanda dalam film Dear White People ini kita bisa melihat tanda yang mereka buat yang menjurus pada rasisme. Misalnya rambut yang lurus hanya untuk ras kulit putih sedangkan rambut keriting penanda ras kulit hitam. Tanda-tanda lainnya terlihat saat pesta Halloween, ras kulit putih berpesta dengan kostum ras kulit hitam. Ada yang mewarnai kulitnya menjadi hitam, menggunakan pakaian $\mathrm{R} \& \mathrm{~B}$ dan menjadi rapper, menggunakan rambut palsu yang keriting, menggunakan topeng muka Obama, dan poster dengan tulisan Missing Black Culture yang berarti budaya kulit hitam yang hilang.

\section{REFERENSI}

Al Hafizh, Muhammad. 2016. Rasisme dalam Masyarakat Pascakolonial: Sebuah Analisis Wacana Kritis terhadap Novel-novel Jacqueline Woodson. Humanus. Vol XV (2):177-194.

Dory. 2014. Dear White People. https://filmbor.com/dear-white-people/. Diakses Pada Tanggal 15 April 2018 Pukul 12.44 WIB.

Jeppesen, Helle. 2010. Apartheid di Afrika Selatan-Dunia HitamPutih.http://www.dw.com/id/apartheid-di-afrika-selatan-dunia-hitam-putih/a-5239303. Diakses Pada Tanggal 15 April 2018 Pukul 09.51 WIB.

Karima, Salyla dan Christin, Maylanny. 2015. Analisis Semiotika Charles Sanders Peirce Atas Presentasi Kekerasan dalam Serial Film Kartun Little Krisha Serial Episode 5 September 2014. E-Proceeding of Management. Vol II (2): 2237-2243.

Kaelan. 2009. Filsafat Bahasa Semiotika dan Hermeneutika. Yogyakarta: Paradigma.

Kurniawan, Doni. 2011. Pesan Anti Rasisme Dalam Film (Analisis Isi Pada Film "Freedom Writers" Karya Richard LaGravenese). Skripsi. Jurusan Ilmu Komunikasi. Fakultas Ilmu Sosial dan Ilmu Politik. Universitas Muhammadiyah Malang.

McAddams, Poppy. 2017. Dear White People. http://cultureremains.com/en/dear-white-peoplenew-netflix-original/. Diakses Pada Tanggal 15 April 2018 Pukul 12.44 WIB.

McQuail, Dennis. 2011. Teori Komunikasi Massa, edisi ke enam. Jakarta: Salemba Humanika.

Minfadlillah, Abd Salam. 2016. Etnosentrisme Rasial Orang Kulit Putih Terhadap Kulit Hitam Dalam Film (Analisis Wacana Kritis Van Dijk Dalam Film Selma). Skripsi. Program Studi Ilmu Komunikasi. Fakultas Ilmu Sosial dan Humaniora. Universitas Islam Negeri (UIN) Sunan Kalijaga Yogyakarta. 
Nisa, Ishmatun. 2014. Analisis Semiotika Pesan Moral Dalam Film Jokowi. Skripsi. Jurusan Komunikasi dan Penyiaran Islam. Fakultas Ilmu Dakwah dan Ilmu Komunikasi. Universitas Islam Negeri Syarif Hidayatulla Jakarta.

Pontoh, Coen Husain. 2016. Mengapa Kita Harus Melawan Rasisme. https://indoprogress.com/2016/07/mengapa-kita-harus-melawan-rasisme/. Diakses Pada Tanggal 15 April 2018 Pukul 11.44 WIB.

Sawitri, Yaninta Sani. 2009. Rasisme dalam Film Crash (Analisis Semiotik tentang Representasi Rasisme di Negara Multi Ras dalam Film Crash). Skripsi. Jurusan Ilmu Komunikasi. Fakultas Ilmu Sosial dan Ilmu Politik. Universitas Sebelas Maret Surakarta.

Shinta, Yulian. 2010. Anti Rasisme Pada Tokoh Erin Gruwell Dalam Film Freedom Writers Karya Richard Lagravenese. Skripsi. Jurusan Sastra Inggris. Fakultas Ilmu Budaya. Universitas Diponegoro Semarang.

Subur, Alex. 2009. Semiotika Komunikasi. Bandung: PT. Remaja Rosdakarya.

Susma, Tiara. 2017. Dear White People Film Sindiran Tentang Isu Diskriminasi Ras.https://www.teen.co.id/read/6348/dear-white-people-film-sindiran-tentang-isudiskriminasi-ras. Diakses Pada Tanggal 15 April 2018 Pukul 12.44 WIB.

Tanjung, Esa Putra. 2017. Macam-macam Genre Film Yang Wajib Kalian Ketahui.https://waktuku.com/macam-macam-genre-film/. Tanggal 15 April 2018 Pukul 12.08 WIB.

Trianton, Teguh. (2013). Film Sebagai Media Belajar, Yogyakarta: Graha Ilmu.

Undang-Undang Republik Indonesia Nomor 40Tahun 2008 Tentang Penghapusan Diskriminasi Ras

Dan

Etnis

Widjaja, Ardian. 2016. Representasi Resistensi Rasisme dalam Film 12 Years a Slave. Skripsi. Jurusan Ilmu Komunikasi. Fakultas Ilmu Sosial dan Ilmu Politik. Universitas Diponegoro Semarang.

WilMacks. 2016. Dear White People: This is Why Black Lives Maker. https://www.pinterest.com/pin/695454367427370256/Diakses Pada Tanggal 15 April 2018 Pukul 12.44 WIB.

Yumni, Akbar. 2013. Sinema Dokumenter Propaganda. http://jurnalfootage.net/v4/sinemadokumenter-propaganda/. Diakses Pada Tanggal 15 April 2018 Pukul 09.40 WIB. 